\title{
ONE TRAUMA, TWO NARRATIVES: ADAMAH VERSUS TOMORROW'S A WONDERFUL DAY
}

\author{
Liat Steir-Livny \\ Associate Professor \\ Sapir Academic College and The Open University of Israel \\ liatsteirlivny@gmail.com
}

\begin{abstract}
In the three years after World War II, prominent Jewish organizations in the United States and in the Land of Israel made films aimed at promoting Zionist goals. The film Adamah (Helmar Lerski, 1948) was produced in the Land of Israel with the support of the Jewish-American volunteer women's organization Hadassah. It tells the rehabilitation story of Benjamin, a Holocaust survivor in the Land of Israel. When the final version was sent to Hadassah for approval, the directorate felt that the American public would not relate to it. Hadassah altered the footage and distributed its own version entitled Tomorrow's a Wonderful Day (1949). This article presents a comprehensive analysis of the main differences between the two representations of trauma, which were taken from the same footage but shaped into two differing narratives. Based on studies in Zionism and a great deal of archival material, it shows how these films epitomized the differences in the perception of trauma and its representations between the Zionist organizations in the Land of Israel and the USA.
\end{abstract}

Keywords: aid organizations, Holocaust, Holocaust cinema, Holocaust survivors, trauma

In the three years after World War II, prominent Jewish organizations in the United States and in the Land of Israel (Hebrew: Eretz Yisrael) made films aimed at promoting Zionist goals (Steir-Livny 2018). The film Adamah (directed by Helmar Lerski, 1948) was produced in the Land of Israel with the support of the Jewish-American Hadassah organization. It tells the story of Benjamin, a Holocaust survivor who makes it to the Land of Israel. Traumatized and haunted by Holocaust experiences, his memories engulf him. Slowly he learns to process the trauma and becomes a hardworking pioneer. The Israeli version, like its American counterpart, was intended to elicit support and raise funds from American audiences. However, when the final version was sent to Hadassah for approval, the directorate felt that the American public would 
not relate to it. Hadassah altered the footage and distributed its own version entitled Tomorrow's a Wonderful Day (1949). ${ }^{1}$

Two previous studies have dealt briefly with the differences between the two films (Mandel n.d.; Deblinger 2014: 121-129). This article presents a comprehensive analysis of the main differences between Adamah and Tomorrow's a Wonderful Day. Based on studies in Zionism and a great deal of archival material about the production of the films, it shows how these films epitomized the differences in the perception of trauma and its representations between the Zionist organizations in the Land of Israel and in the USA. Even though the organizations in both countries appealed to similar target audiences, the different locations in which they operated and their differing immediate agendas led them to construct two separate narratives of the same trauma. The Israeli version emphasized the healing powers of the land and its people, whereas the American version focused on the individual and the personal struggle to rehabilitate.

\section{INTRODUCTION: THE POST-WWII ZIONIST CAMPAIGN IN THE LAND OF ISRAEL AND IN THE USA}

The Zionist cinema in the Land of Israel in the 1940s was dominated by ideological considerations. Films were produced by Zionist organizations such as the Jewish National Fund and the Jewish Foundation Fund. They propagated Zionist notions and were designed to influence Western audiences and alert public opinion, while garnering support and donations. As such, they focused on the Zionist struggle, the establishment of the Jewish state, the importance of the land, and the idea of a "new Jew", a young, strong, handsome pioneer who works the land and is the opposite of the weak "diasporic Jew" (a generalization of the European shtetl Jew) who is detached from the land and who does not know how to defend themselves (Gertz 2004; Shohat 2007).

These films did not deal directly with the Holocaust, but rather focused on the Zionist message derived from the decimation of the six million: the importance of establishing a Jewish state in the Land of Israel. As part of this objective, the complex encounter between Holocaust survivors and Jews already settled in the Land of Israel was reduced to a repetitive narrative in which survivors emerged from the Holocaust to find redemption in the Land of Israel. These films portrayed Holocaust survivors as broken in body and spirit but who, thanks to the land, its healing powers, and its Jewish people, undergo a successful transition from trauma to revival (Zimmerman 2002: 27-124; Gertz 2004: 16-41; Steir-Livny 2009: 7-50). These films thus constituted a political bridge between 
the complex issue of displaced Holocaust survivors and the establishment of a Jewish state in the Land of Israel (Avisar 2011: 51).

In the USA, in the aftermath of World War II, prominent Jewish organizations including the Hadassah women's organization launched media campaigns in which films played an integral part. By the end of the 1940s, Hadassah (founded in 1912) already had a membership of 240,000 in 701 branches throughout the United States (Hadassah Newsletter 1945a). In light of the intensification of the Zionist struggle at the time, the women of Hadassah decided to change their public relations policy and appeal not only to a limited Jewish audience, but to the general public as well. ${ }^{2}$ The goals of the organization at the time were to communicate the urgency of helping Holocaust survivors, to elicit sympathy among the general public for Zionist objectives, and to encourage the American government to support the Zionist struggle (Hadassah Newsletter 1945b). Local Hadassah chapters were directed to use all possible media outlets to convey their message, distribute articles related to Hadassah to local media outlets, host lavish fundraising dinners (Hadassah Headlines 1945a) and disseminate Hadassah's message through speeches, pamphlets, newsletters, films, and radio productions. During that time, Hadassah produced several documentary films including The Forgotten Children (1945), They Live Again (1947), and Do You Hear Me? (1947) (Boim Wolf 2010; Hadassah Headlines 1945b).

The director of the International Film Department of Hadassah was Hazel Greenwald. Despite a lack of formal photographic training, during her long career she photographed subjects in twenty-nine countries. After having met Hadassah founder Henrietta Szold in the Land of Israel in the 1930s, Greenwald became involved in the Youth Aliyah movement, which was set up to help the Jewish youth immigrate from Europe. In late 1946, Greenwald was sent as a special photographer to a displaced persons camp in Italy where numerous Holocaust survivors had been sent. She spoke with children, learned about their traumatic pasts, their rehabilitation through Zionist Hachsharot (pioneer training collectives) (see Yad Vashem) and their hopes to immigrate to the Land of Israel. She also embarked on a photojournalistic campaign and published her impressions in newspapers and in the films she produced (Greenwald 1948).

\section{ADAMAH AND TOMORROW'S A WONDERFUL DAY}

Ben Shemen, a children's village located midway between Jerusalem and TelAviv, was founded in 1927 and headed by Dr. Siegfried Lehman. The village absorbed young people from Europe through the Youth Aliya movement both before and after World War II. Adamah was the initiative of Lehman, who also 
wrote the script. The film was directed by the well-known German director Helmar Lerski, who worked in the German film industry in the 1920s, before going to the Land of Israel in 1931. After integrating into the fledging EretzIsraeli film industry, he directed several short documentaries, including the acclaimed Avoda (Work, 1935) and a short film which was later incorporated into the feature film Miklala lebraha (Out of Evil, Joseph Krumgold, 1951) (Horák 1998: 426-436).

The production of Adamah began in $1946^{3}$ and the filming itself started in March 1947. ${ }^{4}$ The film focused on the story of Benjamin, a teen Holocaust survivor whose entire family had perished at the hands of the Nazis. After surviving the concentration camps, he is sent to Ben Shemen with a group of other orphans. Unlike them, however, his integration proves to be more difficult. Traumatized and haunted by his wartime experiences, he is paranoid, and his memories of the concentration camp pursue him. He steals and hides loaves of bread, his belongings are stored in a bag he hides in case he needs to flee at a moment's notice, and he is incapable of participating in any activities with the other children. Slowly, thanks to the love, understanding, and support he receives in the village and from working the land, he sheds his paranoid diasporic identity and becomes a smiling, confident, hardworking pioneer.

Adamah was marketed to many countries in $1948,{ }^{5}$ and was described as the first film to emerge from the new Israeli State. Although it was a fiction film, it was marketed to the world as a documentary. The marketing material, which was distributed by the Forum Film company, stated that "there are no actors in this film ... the children are acting the story of their own lives", ${ }^{6}$ and the film was screened as part of the documentary film section at the Locarno Film Festival in July 1948. ${ }^{7}$ The actor who played Holocaust survivor Benjamin was indeed a Holocaust survivor named Benjamin Hildesheim, but the similarity ended there. Unlike his character in the film, the real Benjamin had integrated into society relatively easily. His character's inability to fit in, his emotional breakdown, and violent outbursts were figments of the scriptwriter's imagination (although typical of the PTSD of survivors). Other children in the film, actual residents of the Ben Shemen village, also delivered lines from the script rather than presented their authentic stories (Steir-Livny 1998).

After the premiere, the reactions in the Swiss press, for example, were very enthusiastic. The Neue Zürcher Zeitung proclaimed that "the world premiere of the film about Ben Shemen Youth Village in the Land of Israel was undoubtedly the climax of the documentary film competition ... a document of exemplary value that is shocking in its realism and fulfills its humanistic intent". Likewise, the Basel Nachrichten wrote: "The film was an astonishing success ... it is a document of extraordinary importance." The Neue Bundner Zeitung 
stated that "the director has been able to fully create a film of great perfection in all respects ... a work of equal value, both artistically and educationally". Mrs. M. Kinert, the director of the documentary film department at the festival, said that the "wonderful documentary" brought her to tears. ${ }^{8}$

At the end of 1948, Forum Films distributed the film in Israel ${ }^{9}$ where it was also highly acclaimed: the reporter for the Palestinian Post called it "the best Israeli film I have seen so far ... the level of photography is very high... the dialogues in different languages add a sense of realism to the film". Ma'ariv, one of the major daily newspapers, praised the film's many facets: "Landscape, play, moral lesson, a trend towards educational guidance and reality, and the main thing is that you do not have the impression of a propaganda trend ... The boy plays his role with Hollywood talent." A reporter for the daily HaMishmar stated that "it was crucial to put these things on canvas". A correspondent for the newspaper Davar commented that the film increased respect for the country and that "the acting has an unmediated faithfulness to the way of life ... the film educates and exalts the story of the integration of youth from the Diaspora and the love of the homeland ... the participants are not actors at all. Their lives were filmed as they are, without any theatrical makeup. These are the youth in Ben Shemen and these are their lives". ${ }^{10}$ A contributor to the newspaper Kolnoa was impressed by the film's authenticity:

A good documentary film ... reality is present... even though they play themselves, all the boys and girls displayed a special talent and an understanding of their mission and executed their performances faithfully. ${ }^{11}$

A reporter of the newspaper Haaretz joined the praise: "The degree of truth in replicating the atmosphere demands that we sing the film's praises ... the diversity of the types of children and teenagers, each burdened by their own history that is onerous for their souls ... emphasizes the difficulties educators face at this institution". ${ }^{12}$

According to an initial agreement between Lehman and Hadassah, Adamah was released to Hadassah in March 1948 for the exclusive dissemination of the film in the USA. ${ }^{13}$ However, the Hadassah directorate was not pleased with the result. Greenwald claimed that the film was "messed-up" and that it had to be reworked for American distribution, and so they did. The script for the Hadassah version was written by Mina Braunston, the organization's Director of Information, and was produced by Hazel Greenwald, chairperson of the International Film Department of Hadassah. Scenes were cut, moved around, the thematic focus was altered, and the narrator was replaced by an actor who "played" Benjamin's voice-over in the first person. ${ }^{14}$ Lerski was outraged 
by the cinematic and conceptual changes, but could do nothing since he was officially prevented from seeing the new version until it had been completed. In the meantime, the new version, titled Tomorrow's a Wonderful Day, was distributed worldwide (Steir-Livny 2001).

Tomorrow's a Wonderful Day was one of the best-received films at the Edinburgh Film Festival in 1949. ${ }^{15}$ Likewise, it was praised in the American press: The New York Times stated that Tomorrow's a Wonderful Day is "proof that in Israel there are more struggles besides the conflicts of diplomacy and war", and that the film's story and message are very important. Irene Thorer, a reporter for the New York Post, wrote that the film was "a warm and charming display of a child's life in the new country", and that showing Benjamin's ability to overcome his past has educational value and should therefore be shown in schools. ${ }^{16}$ This version also received favorable reviews from Jewish newspapers in Britain. The Zionist Review claimed that it was the most vivid and moving account of the lives of children in Israel. ${ }^{17}$

Films at that time were printed on flammable nitrate material and were prone to spontaneous flare-ups. The reels of Adamah, which were stored in Ben Shemen, combusted in 1960 and set fire to the dining hall of the youth village. The Hadassah organization claimed that it did not have a copy of the film. However, another copy was found after a lengthy search at the Jewish Foundation Fund offices in France. The film was transferred to a film laboratory in Tel Aviv and a $16 \mathrm{~mm}$ copy of the last five minutes was made. Nevertheless, bad luck continued to haunt the film, and a fire broke out in the bank above the laboratory. The water that helped put out the fire damaged the lab and destroyed the copy. Only the last five minutes of the film, plus the later Hadassah version were left, and for many years Adamah was considered a lost film (Steir-Livny 2001). In 2009, the Steven Spielberg Jewish Film Archive received a copy that had been preserved in Europe. According to archive workers, this version comes the closest to the original script, although it is impossible to tell whether it completely matches the original edited film. The film underwent a process of recovery and reconstruction in the archives. ${ }^{18}$

The found version makes it possible to analyze the differences between the Eretz-Israeli and American versions. The changes initiated by Greenwald provide clear examples of the different agendas, goals, and attitudes pertaining to the representation of the trauma and the rehabilitation of Holocaust survivors in both Jewish contexts. While Adamah used the character of a Holocaust survivor to emphasize the importance of the healing power of the land, and the sacrifice necessary to defend it, Tomorrow's a Wonderful Day focuses on the individual and his inner struggle. It highlights the survivor himself and the process of rehabilitation after a trauma that transforms him from a broken adolescent into 
a healthy, functioning young man. Based on studies in Zionism and considerable archival material, the following sections analyze some prominent aspects of the two narratives of trauma and rehabilitation.

\section{TITLES, PERSPECTIVES, AND NARRATION}

The initial goal of Adamah was to highlight the vital role that the Land of Israel (and the youth village) played in the rehabilitation of Jewish orphans, mainly Holocaust survivors. The title of the film (meaning 'soil' in Hebrew) reflects the healing power of the earth. This focus on the land and on space replicates ideas that appeared in other Eretz-Israeli films of that era. Israel was depicted as an agricultural land even though urban settlements dominated and had absorbed a vast majority of the immigrants during the Mandate Period (the British rule of Palestine from 1917 to 1948). Although urban society was central to the Jewish settlement in the Land of Israel, the representation of the Land of Israel as an agricultural land was consistent with the Zionist ideology that emphasized its biblical roots in the land and Zionism as a return of the Jews to a land that was theirs from antiquity. Hence, similar scenes were repeated in many films: verdant fields, beautiful settlements, and tanned, shirtless farmers driving tractors. The bourgeoisie and capitalists were marginalized and were replaced by figures that appeared against the backdrop of the Israeli landscape: strong young men and beautiful women in shorts working the land with apparent joy. Descriptions of development, progress, and prosperity were emphasized. The importance of the land was also evident in the fantasy of large, borderless spaces under Jewish control. The films constructed the space by the repeated use of distant photography of the surroundings (extreme long shots) and by panning (camera movement from right to left or from left to right) to survey large areas dominated by the Jews. This form of image deployment was described by cultural researcher Nurith Gertz as "optimistic geography" (Gertz 2004: 38-39). Since the Land of Israel was the real protagonist of films in the 1940 s, very few scenes are set in closed spaces. Most events, even the most dramatic ones, which naturally might have occurred in more intimate spaces, are filmed outdoors against a backdrop of fields, trails, and roads that overlook the agricultural landscape. The ones that are filmed indoors focus on advances in the arts, crafts, science, and culture.

Consistent with this trend, many scenes in Adamah are set outside. The camera shows the wonders of Ben Shemen: the open paths, the blooming flowers, the sunny agricultural space. The scenes portray prosperity, and the children of Ben Shemen are seen running outside, exercising, and studying. The character of 
Benjamin, wandering aimlessly along the youth village paths, becomes a vehicle for introducing this agricultural world to the audience. Benjamin's integration is symbolized by the connection to the soil. His transformation becomes apparent as he pumps water from the ground and his final integration in the closing scenes is portrayed through this connection with the land. These scenes also depict the work that remains to be done; the reclamation of desolate places (seemingly devoid of Arab settlements) to which the young orphans are sent to settle. They work with tremendous strength and determination to clear away boulder after boulder with their bare hands, as they open the way to prosperity and new settlement.

During the film, the camera lingers on lengthy scenes of life in the children's village, focusing on the importance of the soil in the healing process. The narration explains that "centuries ago, the Jews were a peasant people. The misfortunes of exile cut them off from connection with the soil. It is only natural that their return to Palestine should be a return to the soil" (Adamah).

Moreover, the Israeli version is longer than the American version ( 75 minutes compared to 45 in the American version) and creates a more drawn-out transformation process to emphasize the importance of the land and its people in this change. In this narrative, Benjamin's recovery is attributed to the patience and warmth of the people, and the healing powers of working the land. Each scene in Benjamin's process of change describes another wondrous aspect of his new Eretz-Israeli life through education, culture, and work. As in other Eretz-Israeli Zionist films of that era, the survivor and their rehabilitation are used as a backdrop for showcasing the extent of Zionism in the Land of Israel (Gertz 2004: 18-37; Steir-Livny 2009: 7-50). Thus, the first time we see a smile on Benjamin's face is when he sees Miriam, another resident of the children's village. He also smiles when he hears the children's orchestra rehearse. Then he is taught about the Maccabees, ${ }^{19}$ leads the torch race on Chanukah, joins the Sabbath ceremonies, learns to work the land, pumps water from the ground, and takes part in the Shavuot ${ }^{20}$ harvest ceremony. The narrator mentions that time has passed between scenes, highlighting that this is a long process which relies on the powers of the land and its inhabitants.

The Hadassah organization had a different perspective on the right way to approach the American audience: the organization's aim was to ensure the continuation of donations and to combat "compassion fatigue". Hadassah women were aware that the presence or absence of media attention could be a matter of life and death for populations in distress. The media do not alter the importance of a humanitarian crisis but can change the world's attitude towards it. It is hard to retain public interest in stories of difficult and ongoing catastrophes because the next news event, the next crisis, always diverts public attention. 
Implanting the Holocaust in the American public's consciousness was even more vital because it did not occur on the American soil (Moeller 1999). The images and reports about the Holocaust disappeared relatively quickly from the general press in the aftermath of World War II, both because the Holocaust ceased to be "fresh news", and because of the natural inclination of the public to distance themselves from problems on other continents. Moreover, the new division into two opposing world blocs influenced the American public's emotional distance from the trauma. As the US entered the Cold War and West Germany changed from an enemy to an ally in the war against communism, there was no desire to remind the public of the atrocities committed by the Nazi regime only a few years ago.

Members of American Jewish organizations were forced to face these realities in attempting to raise the awareness of Americans concerning the plight of Holocaust survivors. The reediting of the film by the Hadassah Film Department included changes that reflected Jewish American culture, i.e., what the Hadassah women thought would be most effective. The title was changed from Adamah to Tomorrow's a Wonderful Day. This not only signaled a change in semantics, but also a change in the essence of the narrative itself. The Land of Israel was no longer the protagonist but was replaced by an individual who dreamed of a better future. The title is actually a paraphrase of the famous last line in the film Gone with the Wind, one of America's most popular historical dramas, produced in 1939, which featured a heroine enduring tragedy, yet maintaining her optimism that her fate would be different. This marked a change of focus from the healing power of the land to the power of the individual.

Both versions used an American narrator to achieve identification but did it in a different way. The Israeli version featured the narration of Sam Butler, an American radio anchor and former sports star, who accompanies Benjamin's journey as a third person spectator. In the American version, Jimmie Lipton, a young American actor, tells Benjamin's story after his rehabilitation, as he looks back on his first days in Ben Shemen. Benjamin's interpretation of the events reveals a complex process in which he is also an active participant in his transformation. He is not portrayed as a passive figure, dependent on the kindness of his new country and the healing power of its soil, but as a traumatized teen who must harness his own determination, with the help of others, to achieve complete recovery. The voice-over of Benjamin tells his story in retrospect, now that he is a "new Jew" and is capable of reflecting on the adolescent he used to be. It describes his inner world to the audience. Through the voice-over, the audience learns about a wounded and traumatized individual who shares his experiences and feelings, his fears, anxieties, and insecurities as compared to the free children of his new country, such as his initial suspicions about the 
good intentions of the other young people, his misunderstanding of their excitement at greeting him and the other newcomers. This is not an introduction to the village, but a preview of Benjamin's state of mind and his confusion about everything that happens to him upon his arrival.

For example, in the Israeli version, when he gets to Ben Shemen, Benjamin appears fearful, and is unwilling to talk to the residents. The narrator in the Israeli version states that he is different from the other children. The narrator explains: "You didn't even remember what home feels like. 'Home' to you was Auschwitz, Buchenwald, Theresienstadt. Concentration camps. You didn't talk and you didn't want to be talked to. All you wanted was to be left alone." In the American version, Benjamin tells the audience about his fears, and delusions, which anchor the main theme of the film - the journey of the individual towards salvation. "When I got off [the bus], somebody tried to take my things. 'No, I said. No." What was described in the Israeli version in the third person by a narrator is seen in the American version through Benjamin's point of view. The voice-over mellows Benjamin's harsh image and enables viewers to relate to what he is going through: "The other [children] walked across the grounds like sheep ... It is a habit you get when you live in a concentration camp. They just sat where they were told. They were used to it." Still in survival mode, Benjamin wonders if there is barbed wire in this village. Will it be hard to escape? As he puts it, to him this is "just another concentration camp". Another scene in which Benjamin is shown hiding bread differs greatly in its relatability. The narrator in the Israeli version explains the boy's actions as a general comment relating to all survivors ("There might not be any bread tomorrow. There might not even be a tomorrow") while the American voice-over of Benjamin personalizes the action. "Now I have bread," he says with excitement. The use of voice-over in the American version gives the character of Benjamin a depth which is absent in the Israeli version. It enables the audience to become familiar with the young survivor and to internalize his thoughts, fears, nightmares, and dreams. The voice-over creates intimacy and enables more audience identification than a formal summary told in the third person.

\section{THE FENCE SCENE}

The Israeli version includes two scenes in which Holocaust memories are acted out visually. The first one occurs when Benjamin is wandering down the paths of the children's village and suddenly hears a song that was sung in the concentration camp. As he comes closer to the singers, he suddenly has a flashback. The camera shows a documentary footage of a barbed wire fence, 
as a weeping survivor shows a number tattooed on her arm. ${ }^{21}$ The camera then returns to Benjamin in the present, who runs away. The second scene takes place at a fence in the children's village. In the Israeli version, the fence scene takes place during the first part of the film and is meant to illustrate a crucial transformation. Benjamin has been asked to go with other children to work in a field, but this kind of labor has no Zionist meaning for him, since he sees no value in the soil. For Benjamin, digging the ground reminds him of digging graves in the concentration camp. As the narrator says, "Work is work. Barbed wire is barbed wire." The barbed wire acts as a trigger for Benjamin, who has a flashback to the barbed wire fence in one of the camps. The image of a Nazi whipping a prisoner is presented, and as the whip strikes, Benjamin flinches visibly, as though he is being struck in the present. In a sudden act of rage he starts to tear down the fence, beating it hard with his ax. The cows stampede, ruining the field. Benjamin falls to the ground, as the narrator explains: "What is a nightmare, and what is reality? When does a terrible dream of the past break off and the actuality of the present begin?" As the camera focuses on the number tattooed on his arm, the narrator adds: "Past, present, future. Everything is so confused in your brain. And the others? You have ruined their work. They will never understand." During the next sequence which shows the celebration of Chanukah, the narrator refers to the previous scene: "You were wrong, Benjamin," he says, "they do understand and they want to help teachers and children alike." With this realization, and Benjamin's acceptance of help, the children and the staff together guide Benjamin down his long road towards his eventual healing.

As noted, the American version of the film is shorter. Many scenes of the village showing the children in groups dancing, running, studying, and working were cut or considerably shortened. The Hadassah women focused more on the individual and less on his surroundings. The fence scene takes place in the middle of the film (min. 20). Viewers hear Benjamin telling his story, justifying his violent behavior, and explaining why his memories made him act out: "I saw them [the children working] and thought: 'forced labor again' ... The cows scared me. The sight of those bent backs was like touching a raw nerve. Fresh earth reminded me of just one thing - graves." Since it is the older, rehabilitated Benjamin whose voice-over the viewers hear, naturally some of his memories are fuzzy or have been blocked out. He recalls that he did not want to eat with the other children who were taking a lunch break ("I didn't trust them") and when he passed by the barbed wire fence, he broke down. Documentary shots of a concentration camp's barbed wire are shown and the camera rolls in a loop, combining past and present, as Benjamin describes what was happening in his traumatized mind. 
Suddenly something hit me, right in the back. It was awful. I swear to you I saw the camp, the wire; I touched it, I felt it like something in a nightmare. The barn behind the wire became a death camp and my turn was next... down it came, the whip, the whip.

The scenes in which he damages the fence are explained as his hallucinatory revenge:

And then, it was a miracle that happened. I was going to fight back ... it's different now; this time I'll kill you ... I'm strong, I'm young, I can escape ... then the cows came through the hole in the fence ... and I hit them too.

He also explains how the outburst ended:

It was the smell that really got me out of the fog. I looked down and I saw what I had done. They saw it too [the other children] and for the first time I saw it through their eyes. God was good to me, Miriam. I, who was 15 for the first time in seven years, bowed my head and wept.

After this catharsis, he is able to begin his emotional journey towards a full recovery.

Freud considered melancholy and mourning to be two contradictory forms of coping with trauma: an individual in a melancholic state identifies with the lost object, obscuring the differences between the individual and the object, thereby damaging the ego. In contrast, the mourner undergoes a healthy process of internalization; he or she can deal with the past by creating distance from it. Mourning brings with it the possibility of starting a new life, and any interruption to this process can be harmful. Freud considered one of the central concepts of trauma to be 'repetition compulsion'; i.e., returning to a trauma while blurring the boundaries between past and present, and thus re-experiencing it. This repetition causes suffering and works against the desires of the sufferer (Freud 1978; 2002: 138-171).

Freud's students broadened the debate on trauma and its immediate and later symptoms such as post-traumatic stress disorder (PTSD) which entered the DSM (Diagnostic and Statistical Manual of Mental Disorders) in 1982. It is considered an extremely common mental disturbance among people who have undergone traumatic incidents. Its sufferers continue to experience the traumatic events even after they are over. One of its main characteristics is that the trauma is re-lived by the individual through intrusive, recurrent recollections of the past in the present (PTSD 2013: 271-280).

Drawing on the Freudian tradition, Dominick LaCapra's work on trauma distinguishes between two forms of reactions of people who underwent traumatic 
events. The first is "acting out": the past is not construed as a series of remote events that are long gone or a distant memory but is reborn and experienced as though integral to present-day social and cultural life. The second form is "working-through": clear boundaries are maintained between past and present, and there is awareness of the differences between "then" and "now", with less identification with the assimilation of the traumatic period. While there is also a return to the past in "working-through", it is accompanied by conscious control of the past, maintaining a critical distance from it, and viewing it from a distant perspective (LaCapra 2000: 87-90).

During the 1940s, when so little was known about trauma and the acting out of traumatic memories, the two versions of the fence scene were rare examples of an attempt to explain the enormous disparities in survivors' reactions to trauma. The American version of the film is far less visually impressive, since many of Lerski's pathos-ridden heavy montages are missing. However, unlike the Israeli version, the American version is one of the only creative endeavors of this period, which enabled the audience to enter into the traumatic turmoil emanating from a survivor's soul. Benjamin's voice-over gives the audience the ability to look into his inner being, and also hints at a change he himself enacted: he has not healed through the help of the people around him as in the Israeli version, but has made the transformation himself. According to the American version, this transformation is based on his realization that he was mistaken. When he says: "I saw it through their eyes," he is finally looking at himself and his situation critically. For the first time, he understands the consequences of acting out, and begins to change his behavior. He also recognizes the boundaries between past and present, which represents a big step in working through his trauma.

\section{THE CLOSING SCENES}

The Chanukah scene, which appeared in the middle of the film in Adamah and marked the beginning of Benjamin's rehabilitation process, became the closing scene in Tomorrow's a Wonderful Day (Mandel n.d.; Deblinger 2014: 121-129). The settlement-building scenes, which formed a lengthy conclusion in the Israeli version, were shortened and given less prominence in the American version, where they simply marked another step in his social-emotional recovery. These changes epitomize the differing agendas of Eretz-Israeli and American Zionism.

Eretz-Israelis focused on the land as a Zionist political statement of a society influenced by socialistic ideas, so that the final step in Benjamin's rehabilitation was the building of a new settlement. 
The land as a healing power is presented as the answer to all of Benjamin's problems. The narrator assures Benjamin and the audience that "there are no more memories to hold you back", as the smiling young man dances in the sun with the other young survivors. The concluding scene is the final triumph of this narrative, since according to the film, after the UN partition plan and the beginning of the 1948 war, young people from Ben Shemen set out to build a new settlement. Here the focus is not on Benjamin. Instead, a vast majority of the scenes are group shots. Benjamin is seen as a part of a group, a process, part of a project larger than all of them together.

Lerski was a socialist and the ideas of a group return to the land, visualization and fetishization of physical work coincided with the Zionist project (Mandel n.d.). "Your lives there will be dangerous and tough," says the guide to the youngsters before they leave Ben Shemen to find the new settlement, but no one flees. The camera follows Benjamin and his friends as they happily load trunks on a truck on their way to the "hill of Youth Aliya". The camera follows the truck, as it traverses empty lands, as if nothing in the country exists but Ben Shemen and the new settlement they will build. As they drive to their destination, the theme song of the film is heard in the background. It is Abraham Brody's Adamah, which glorifies the soil as the center of being. "Earth, earth, you are our mother. You are the mother of all men and of all life!" The narrator focuses on the wasteland: "It will take hard work to build a nation out of this wilderness." He describes how they will transform the malarial swamps into a country, and the stony hills will become a home. "But you are not alone. There are others on the bus, and other buses, and men, women, and children all over the world." The narrator thus recruits the audience, turning them into full participants in the project. There are those who will do the work with their hands, and those who will make it happen with their money.

At no point in the very lengthy "new hill" sequence do the youth rest. They are in constant movement, lifting boulders, walking from place to place, riding horses. The narrator points out the hard labor, the sacrifice. For him, this sacrifice is a given. "It won't be easy ... there will be disappointments and defeats. A nation, like a child, cannot be born without pain. This is your challenge, and you are ready for it." The camera pans over the wilderness and then turns to a series of close-ups of huge boulders that must be uprooted. The multiple close-ups of the attempts to move the rocks are combined with low-angle shots of the young men straining in their labor, their muscular arms and their hands grasping hard as they try to move the rocks. These shots are edited as a montage to create the image of a joint venture of which Benjamin is a part. He is, however, not the center. The land is the protagonist and it receives the most screen time. "Each stone that you drag away conquers a new piece of home- 
land," the narrator explains to Benjamin and to the viewers. "Your hands are bruised and your muscles ache, but you don't even notice because you know you are building something; something no one is going to take away from you." Their tenacity is reflected in the long screen time. There are no shortcuts. "Rock after rock, day after day, for a hundred days." The camera is in constant movement through a series of montages which combine pans of the new wall being built, tilts of digging in the ground and photomontages of the youngsters and the land. The soil is visualized as part of the body, of themselves. "Your elders have conquered the Jewish state. It is your job to keep it," says the narrator after the 100th day, explaining the role of the youngsters in the building of the Jewish state.

The only time Benjamin stops to rest is when other youth from Ben Shemen come to visit him after one hundred days of constant work, and even then, it is only a short moment of respite. He receives a message from Miriam, which contains only one sentence: "A man has only as much heaven above his head as he has earth under his feet." This is the same motto he saw Miriam writing on a big poster during his first days in Ben Shemen, but at that point he had not understood. She had promised him that one day it would become clear. And indeed it has. As he reads the sentence he has now come to understand, he jumps to his feet once again and continues to plow the field. The camera focuses on the plowed ground, on close-ups of barefoot children's feet walking straight and sure, and then turns into a superimposition of the feet and the soil, as the narrator repeats the above sentence, explaining that this will become the home for many other children like Benjamin. The film ends with a superimposition of Benjamin and his friends, groups of new children coming to the new settlement, and the soil, while the Hatikva anthem ${ }^{22}$ is heard in the soundtrack. In the final shot, the camera tilts from the ground to the sky. This is not the story of an individual, but of the land itself. Benjamin is part of a generation who has been healed by the soil and whose destiny is to work the land, and even sacrifice himself for the soil. The nation has won.

Whereas pioneering was very impressive in the eyes of American Jews, socialism was not, but Jewish tradition was something they could actually relate to. Thus, in the American version, the Chanukah scenes end the film as they represent the ultimate transition from darkness to light, from Holocaust to revival. The holiday carries with it the symbol of transition from spiritual persecution to religious and political freedom, but above all, the torch relay signifies one boy's journey from Holocaust to redemption. The American version focuses on the triumph of an individual, which culminates in Benjamin's selection to head the traditional torch relay (from Modi'in where the Maccabees are buried to Ben-Shemen). The camera focuses on him leading the way for 
the other young people who are running with him, holding a torch and lighting the dark path. He runs towards the village as the older Benjamin recalls the transformation he has undergone, and his new awareness:

It was as if a great door had opened to me. I said to myself: you who have no father are now a son in Israel. Kindle the light and run, Benjamin! Run! Run from the hill of sorrow and leave it behind you ... hold your head high. They all seem to be calling out to me: 'Run for your village, Benjamin. We need you, Benjamin. Run for your country. You are not alone. Behind you lies the blackness of our history; before you a new life. You are the first. So run, Benjamin. Up there is the door, up there is your victory.' Now I knew it was a race for life.

When he gets to Ben Shemen, Benjamin enters a hall. The children, assembled in two parallel lines, stand in the shadows, while the light is concentrated in the middle, where Benjamin strides with his torch. Even in this scene he is visually an individual. He recounts: "I, too, now fit like a fragment. A small stone in an ancient pattern." The camera, however, continues to emphasize his individuality, as it closes in on his face, as he sings and looks toward the horizon. The American version ends with expressions of gratitude to God, not to the soil. "Thank you, God," says Benjamin, after placing the torch in the hall "for myself and for Israel". This is a completely different narrative than the secular Israeli version, which turned the land into something sacred, and made people the agents of change. This switch from divine to human supremacy also appeared in many other Israeli contexts during this time (Shapira 1998: 415-441). By contrast, Greenwald included segments that Jewish American viewers would recognize, such as the Chanukah blessing. In this way, she sought to connect the more "foreign" concepts, such as the idea of a collective children's village, to more familiar Jewish elements, thus bringing the audience closer to the narrative. In order to highlight the prayer, it appears twice, once as a child lights the candles and chants the blessing in Hebrew, and a second time in Benjamin's voice-over as he repeats it, this time in English. The "Maoz Tzur" song is treated similarly: the camera pans over the children singing it in Hebrew, then Benjamin can be heard translating it into English. "Never again will it be dark for me," he says. The Israeli version concludes with a series of group shots that include Benjamin, and which emphasize the importance of the collective building of new settlements, whereas the American version concludes with a shot of Benjamin standing in the forefront, near the menorah, while Ben-Shemen's children are in the background. Here too, he is part of the collective, but he has maintained his individuality. The camera zooms in on his face as he sings. The individual has won. 


\section{TWO NARRATIVES OF THE SAME TRAUMA}

The comparison of the two versions of the same story about a traumatized Holocaust survivor highlights the differing perspectives of American and EretzIsraeli Zionist organizations in the 1940s with respect to trauma and rehabilitation. The Jewish organizations in the two countries affected public opinion in their countries and in turn were affected by them. The differing circumstances and environments in which they operated created two distinct narratives of the same trauma.

The Israeli version was a national narrative that focused on the land, while the Jewish American plot focused on the individual, and the personal strengths that played a role in the transition from physical and spiritual enslavement to freedom. These changes are expressed in the titles of each film, the narration/ voice-over, and the editing of the scenes. These differences reflect two Zionist representations of the same trauma and two different approaches to dealing with it: one that relies on the community and the land and the other that relies on the individual.

In a nutshell, these two traumatic narratives capture the differences between prominent myths of mainstream Israeli and American Jews in the 1940s; namely, the "American Dream" which focuses on individuals and their ability to realize their dream as compared to the Eretz-Israeli myth of the transition from the "diasporic Jew" to the "New Jew" through the succor of the land and its people.

These differences also emerge when comparing other Zionist films produced in the Land of Israel to Zionist productions in the USA between 1945 and 1948 (Steir-Livny 2018). It would be worthwhile to explore whether these separate narratives continued to be represented in the 1950s, after the goal of the founding of the State of Israel had been achieved.

\section{NOTES}

1 For the American version see: The Spielberg Jewish Film Archive: Tomorrow's a Wonderful Day, available at https://www.youtube.com/watch?v=9iXkhML3MHk, last accessed on 21 April 2021. The Israeli version is available on CD.

2 “The Forgotten Children", Hadassah File. The Steven Spielberg Jewish Film Archive.

3 The board of Ben Shemen to Leibush, Kvutzat Geva, 6 September 1946, Adamah File. The Steven Spielberg Jewish Film Archive.

4 Ben Shemen Board to Exelrod, 21 March 1947, Adamah File. The Steven Spielberg Jewish Film Archive. 
5 Including France, Belgium, Italy, Hungary, Switzerland, Sweden, Netherlands, Australia, New Zealand, Ecuador, Colombia, Venezuela, Brazil, South Africa, and others. See Internal Memorandum 1949, Adamah File. The Steven Spielberg Jewish Film Archive.

6 Adamah File, The Steven Spielberg Jewish Film Archive.

7 Telegram from Lehmann to Kramersky, May 25, 1948, RG 1 (Youth Aliyah). Carton 40, Box 2. Dr. Siegfried Lehmann 1946-1948. Hadassah Archive, NY.

8 Newspaper Review, The Israel Defense Forces and Defense Establishment Archive (IDFA), S75/1629.

9 Application form to the Film Review Board, Israel State Archives, September 7, 1948. MB 22/3605.

${ }^{10}$ Adamah File, The Steven Spielberg Jewish Film Archive.

${ }^{11}$ Adamah File, The Steven Spielberg Jewish Film Archive.

${ }^{12}$ Adamah File, The Steven Spielberg Jewish Film Archive.

${ }^{13}$ Siegfried Lehmann to the Hadassah chairman, March 2, 1948. Adamah File, The Steven Spielberg Jewish Film Archive.

${ }^{14}$ Miriam Warburg, Youth Aliyah branch in London, to George Landauer, July 26, 1948. IDFA, S75/1629; Adamah File, The Steven Spielberg Jewish Film Archive; Promotional pamphlet Tomorrow is a Wonderful Day, undated, IDFA, KH4/B/5356; Siegfried Lehman to Hazel Greenwald, July 21, 1947 RG 1 (Youth Aliyah), Carton 40, Box 2. Dr. Siegfried Lehman 1946-1948, Hadassah Archive, NY; RG 1 (Youth Aliyah), Carton 40, Box 2. Dr. Siegfried Lehman 1946-1948. Hadassah Archive, NY.

${ }^{15}$ Adamah Catalog, The Steven Spielberg Jewish Film Archive, p. 19.

${ }^{16}$ Articles from April 1949, Adamah File, The Steven Spielberg Jewish Film Archive.

17 Tomorrow's a Wonderful Day. Zionist Review, June 3, 1949, London, IDFA, KH4/B/5356.

${ }^{18}$ Adamah, booklet accompanying the film, 2010, the Steven Spielberg Jewish Film Archive.

${ }^{19}$ A group of Jewish rebels who freed Judea from the rule of the Seleucid Empire and founded an independent Jewish state between 167 to $37 \mathrm{BCE}$.

${ }^{20}$ Jewish holiday which marks the wheat harvest.

${ }^{21}$ The footage was taken from a Soviet documentary of Auschwitz and Majdanek. See a letter to the USSR Society for Cultural Relations with Foreign Countries, March 13, 1947. Adamah File, The Steven Spielberg Jewish Film Archive.

${ }^{22}$ National anthem of Israel. 


\section{REFERENCES}

Adamah. Dir. Helmar Lerski. 1948. Film.

Avisar, Ilan 2011. The Holocaust in Israeli Cinema as a Conflict between Survival and Morality. In: Miri Talmon \& Yaron Peleg (eds.) Israeli Cinema: Identities in Motion. Austin: University of Texas Press, pp. 151-167.

Boim Wolf, Rebecca 2010. It's Good Americanism to Join Hadassah: Selling Hadassah in the Postwar Era. In: Hasia Diner \& Shira Kohn \& Rachel Kranson (eds.) A Jewish Feminine Mystique? Jewish Women in Postwar America. Rutgers University Press, pp. 65-86.

Deblinger, Rachel Beth 2014. "In a World Still Trembling": American Jewish Philanthropy and the Shaping of Holocaust Survivor Narratives in Postwar America (1945-1953). Diss. (PhD Thesis). University of California. Available at https://escholarship. org/uc/item/2v08154g, last accessed on 28 April 2021.

Freud, Sigmund 1978. Beyond the Pleasure and Other Works. Tel Aviv: Dvir. (In Hebrew) Freud, Sigmund 2002. Psychoanalytic Treatment. Tel Aviv: Am Oved. (In Hebrew)

Gertz, Nurith 2004. A Different Choir: Holocaust Survivors, Foreigners, and Others in Israeli Cinema and Literature. Ra'anana: Open University of Israel Press. (In Hebrew)

Hadassah Newsletter 1945a = Publicity and Promotion. Hadassah Newsletter, November, pp. 35-36.

Hadassah Newsletter 1945b = Our Fight Begins. Hadassah Newsletter, November, p. 2. Hadassah Headlines 1945a = Ideas of the Month. Hadassah Headlines, October, p. 5.

Hadassah Headlines 1945b = Youth Aliyah - Fulfilling a Promise. Hadassah Headlines, May, p. 4.

Horák, Jean Christophe 1998. The Penetrating Power of Light: Helmer Lerski's Films. In: Nurith Gertz \& Judd Ne'eman \& Orly Lubin (eds.) Fictitious Looks on Israeli Cinema. Tel Aviv: Open University, pp. 436-426. (In Hebrew)

LaCapra, Dominick 2000. Writing History, Writing Trauma. Baltimore, MD: The Johns Hopkins University Press.

Mandel, Karnit n.d. Helmar Lerski's Cinema: Propaganda and Art. Takriv.net. Available at https://takriv.net/article/\%D7\%94\%D7\%A7\%D7\%95\%D7\%9C\%D7\%A 0\%D7\%95\%D7\%A2-\%D7\%A9\%D7\%9C-\%D7\%94\%D7\%9C\%D7\%9E\%D7\%A8$\% \mathrm{D} 7 \% 9 \mathrm{C} \% \mathrm{D} 7 \%$ A $8 \%$ D $7 \%$ A $1 \%$ D $7 \%$ A $7 \%$ D $7 \% 99-$ \%D7\%AA\%D7\%A2\%D7\%9E\%D7\%95\%D7\%9C\%D7\%94-\%D7\%95\%D7\%90\%D7 $\% 9 \mathrm{E} \% \mathrm{D} 7 \% \mathrm{~A} 0 \% \mathrm{D} 7 \% 95 \% \mathrm{D} 7 \% \mathrm{AA} /$, last accessed on 7 June 2021.

Moeller, Susan D. 1999. Compassion Fatigue: How the Media Sell Disease, Famine, War and Death. New York: Routledge.

PTSD 2013 = PTSD. In: Diagnostic and Statistical Manual of Mental Disorders. 5th ed. Washington, DC: American Psychiatric Association Publishing, pp. 271-280. https://doi.org/10.1176/appi.books.9780890425596.

Shapira, Anita 1998. The Religious Motives of the Labor Movement. In: Yerahmiel Cohen (ed.) Studies in the History of Israel in the New Era. Jerusalem: The Zalman Shazar Center, pp. 415-441. (In Hebrew)

Shohat, Ella 2007. Israeli Cinema: East/West and the Politics of Representation. Ra'anana: Open University of Israel Press. (In Hebrew) 
Steir-Livny, Liat 1998. An interview with Richard Levison, a counselor at Ben Shemen youth village, and the photographer of the film Adamah. 7 January. (Manuscript in Hebrew)

Steir-Livny, Liat 2001. An interview with Hillel Treister, Film Scholar and Deputy Director of The Steven Spielberg Jewish Film Archive. 20 May. (Manuscript in Hebrew)

Steir-Livny, Liat 2009. Two Faces in the Mirror: The Representation of Holocaust Survivors in Israeli Cinema. Jerusalem: Magnes. (In Hebrew)

Steir-Livny, Liat 2018. One Trauma, Two Perspectives, Three Years. Haifa: The Herzl Institute for the Study of Zionism: University of Haifa. (In Hebrew)

Tomorrow's a Wonderful Day. Dir. Helmar Lerski. 1949. Film.

Yad Vashem = DP Camps and Hachsharot in Italy after the War. Available at https:// www.yadvashem.org/yv/en/exhibitions/dp_camps_italy/index.asp, last accessed on 4 June 2021.

Zimmerman, Moshe 2002. Do Not Touch My Holocaust. Haifa: Haifa University Press. (In Hebrew)

Liat Steir-Livny is Associate Professor at the Department of Culture at Sapir Academic College, and an advisor and course coordinator for the Cultural Studies MA program at the Department of Literature, Language, and the Arts at the Open University of Israel. Her research focuses on Holocaust commemoration in Israel from the 1940s until the present. It combines Holocaust studies, memory studies, cultural studies, trauma studies and film studies. She is the author of numerous articles and five books.

liatsteirlivny@gmail.com

www.liatsteirlivny.com 